Yıl: 23 Cilt: 23 Sayı: 2 Aralık 2021 s.267-285 Makale Türü: Araştırma

Makalenin Geliş Tarihi: 09.06.2021 Makalenin Kabul Tarihi: 16.11.2021

\title{
İkinci Dağlık Karabağ Savaşı Işı̆̆ında İsrail-Azerbaycan İlişkileri: Yapısal ve Analitik Bir Çerçeve
}

\section{Ceyhun Çiçekçi*}

Öz: İsrail-Azerbaycan ilişkileri, İkinci Dağlık Karabağ Savaşı sürecinde yeniden gündeme gelmiş ve kamusal/akademik tartışmaların konusu olmuştur. Özellikle de İsrail'in Azerbaycan'a verdiği destek, bilhassa da Azerbaycan ordusunun kapasitesine yaptığı olumlu katkılardan dolayı, Ermenistan ve destekçilerinin yoğun eleştirilerine maruz kalmıştır. Bir yandan da Türkiye-İsrail ilişkilerinin uzunca bir süredir negatif bir seyir izlemesi, İsrail-Azerbaycan ilişkilerinin başarısının analiz edilmesi noktasında akademik bir motivasyon sağlamaktadır. Bu çalışmada, İsrail-Azerbaycan ilişkilerinin üç ayrı analitik düzlemde incelenmesi öngörülmektedir. Bu bağlamda, Uluslararası İlişkiler disiplininin bilimsel enstrumanlarından olan analiz düzeyleri yaklaşımı çerçevesinde ikili ilişkiler; uluslararası, bölgesel ve ulusal düzeylerdeki etkileşimleri esas alınarak tartışılacaktır. Ayrıca ikili ilişkilerin boyutları, tehdit dengesi teorisi çerçevesinde test edilecektir.

Anahtar Kelimeler: İsrail, Azerbaycan, Dağlık Karabağ, Analiz Düzeyleri, Tehdit Dengesi

* Öğr. Gör. Dr., Bandırma Onyedi Eylül Üniversitesi, Erdek MYO, Yerel Yönetimler Programı, E-Mail: ccicekci@bandirma.edu.tr, ORCID: 0000-0002-5036-537X 
Year: 23 Volume: 23 Issue: 2 December 2021 p.267-285 Article Type: Research Received Date: 09.06.2021 Accepted Date: 16.11.2021

\title{
Israel-Azerbaijan Relations in the Light of Second Nagorno- Karabagh Conflict: A Structural and Analytical Framework
}

\section{Ceyhun Çiçekçi}

\begin{abstract}
Israel-Azerbaijan relations had repeatedly been a hot topic in public/academic debates in the process of Second Nagorno-Karabagh War. Particularly the heavy support of Israel to Azerbaijan was hugely targeted by Armenia and her supporters, especially in the meaning of Israeli contributions to the capacity of Azerbaijani army. On the other hand, the deteriorated course that Turkey-Israel relations has paved for a long time, provided an academic motivation to analyze the success of Israel-Azerbaijan relations. In this study, it is predicted that Israel-Azerbaijan relations would be analyzed by three separate levels. In this context, by basing on international, regional and national levels, the interactions of bilateral relations will be debated in the framework of the levels of analysis, one of the main scientific instruments of International Relations discipline. Furthermore, the dimensions of bilateral relations will be tested within the scope of balance of threat theory.
\end{abstract}

Keywords: Israel, Azerbaijan, Nagorno-Karabagh, Levels of Analysis, Balance of Threat 


\section{Giriş}

2020 yılının yaz ayları itibariyle Azerbaycan ile Ermenistan arasında yeniden alevlenen Dağlık Karabağ sorunu, yoğun bir askeri çatışma sürecine evrilmiş ve sonuç olarak Azerbaycan'ın uluslararası hukuk nezdinde meşru toprağı kabul edilen Dağlık Karabağ’da yeni bir status quo oluşmuştur. Bu bağlamda Azerbaycan kuvvetleri, Dağlık Karabağ'ı ele geçirerek, bölgesel dinamiklerin ve dengelerin yeniden gözden geçirilmesine sebep olmuştur. Bu çalışma da böylesi bir sonucun başat tetikleyicilerinden biri olarak kabul edilen Azerbaycan'ın İsrail ile ilişkilerini mercek altına alarak, özellikle de İkinci Dağlık Karabağ savaşının ortaya çıkarttığı konjonktür çerçevesinde bir değerlendirme yapma amacındadır.

İsrail-Azerbaycan ilişkilerinin stratejik doğası, özellikle de İkinci Dağlık Karabağ savaşı süresince tekraren önemi anlaşılmış bir olgu olarak durmaktadır. Söz konusu stratejik ilişkiler ve özellikle de Azerbaycan ordusunun silah envanterine İsrail'in yaptığı katkılar ${ }^{1}$, Azerbaycan-Ermenistan dengesinde yarattığı belirleyici etki nedeniyle, savaş süresince Ermenistan'ın hedefi olmuştur. Hem Ermenistan devlet ricalinden Azerbaycan'a yapılan silah transferlerinin durdurulması konusunda İsrail'e yoğun tepkiler yöneltilmiş ${ }^{2}$ hem de Ermeni lobisinin önde gelen kuruluşlarından kimseler, İsrail medyasında yer bulan görüş yazıları kaleme almışlar ve İsrail'in Azerbaycan'a verdiği desteği eleştirmişlerdir (Sassonian, 2021). Bu açıdan bakıldığında, Azerbaycan'ın İsrail'le geliştirdiği ilişkilerin ulusal güvenlik odaklı bir nitelik arz etmesi, İkinci Dağlık Karabağ savaşı boyunca Ermeni tarafını rahatsız etmiştir. Bu savaş kapsamında İsrail, hem ilişkilerinin uzun bir süredir kötüleştiği Türkiye ile hem de sözde Türkiye’nin bölgeye gönderdiği Suriyeli cihatçı milislerle aynı safta bulunmakla itham edilmiştir (Irish ve Rose, 2020). Lakin yine İsrail medyasında görülebileceği üzere, çeşitli kanallar üzerinden verilen cevaplar, İsrail'in Azerbaycan'a verdiği desteğin güçlü bir biçimde sürdüğünü ve süreceğini göstermektedir (Sneh, 2020). Kuşkusuz ki İsrail tarafının söz konusu ithamlara rağmen Azerbaycan’a verdiği destek, titiz bir incelemeye konu olmayı hak ediyor.

İsrail-Azerbaycan ilişkileri, literatüre güçlü bir biçimde yansıdığı ölçülerde, İsrail merkezli bir politikanın devamlılığına işaret etmek çerçevesinde

\footnotetext{
1 İsrail-Azerbaycan arasındaki silah ticaretinin hacmi konusunda çeşitli rakamlar kamuoyuna yansımış durumdadır. Bu çerçevede, Stokholm Uluslararası Barış Araştırmaları Enstitüsü'nün ulaştığı rakamlara göre İsrail, Azerbaycan ordusunun silah ithalatında \%26'dan fazla bir paya sahiptir. Kıyaslamalı olarak bakıldığında, Ermenistan ordusunun neredeyse bütün silah ihtiyacını temin eden Rusya'ya nazaran Azerbaycan, silah tedarik kanallarını çeşitlendirmiş gözükmektedir (Wezeman, Kuimova ve Smith, 2021).

2 Bu bağlamda, Ermenistan'ın Tel Aviv Büyükelçisi Armen Smbatyan İsrail'e yönelik diplomatik bir protesto amacıyla geri çağrılmıştır. Ayrıca Smbatyan'ın Ermeni gazetelerine verdiği demeçlerinde de İsrail'e yönelik tepki öne çıkmaktadır (The Times of Israel, 2020).

Ayrıca Ermenistan Dışişleri Bakanı’nın açıklamaları da bu bağlamda önem taşımaktadır (Katz, 2020).
} 
anlaşılmaktadır. Bu bağlamda, İsrail dış politika ve ulusal güvenlik politikası tarihinin önemli bir kavramsallaştırması olarak Çevre(sel) Pakt, İsrail-Azerbaycan ilişkilerini anlamlandırabilmek adına kullanılan politik-akademik araçlardan birisidir. $^{3}$

İlgili literatüre göre, İsrail'in Azerbaycan'a yönelik politikası, ilk versiyonu 1950’li yıllarda Türkiye'nin de dâhil olduğu bir grup Arap olmayan ülkelerle geliştirilen ilişkileri çerçevelemek için kullanılan Çevre(sel) Pakt politikası bağlamında anlaşılmalıdır (Özdaşlı, 2017; Pinfold ve Peters, 2021; Guzansky, 2014). Buna göre Azerbaycan, İran'la güneyinden sınırdaş olması hasebiyle, İsrail'in yakın çevresinde ve özellikle İran’ı dengelemek adına kurgulamak istediği ittifakvari ilişkilerin bir parçası olarak telakki edilmektedir. Fakat burada gözden kaçan bir husus, orijinal bağlamıyla Çevre(sel) Pakt'ın tamamıyla Arap dünyasına yönelik kurgulanmış bir içerikte olmasıdır. Bir diğer ifadeyle İsrail, Arap devletleriyle çevrili bir coğrafyaya sahip olmasından ötürü, yine bu devletleri dengeleyebilmek adına, jeopolitik bir anlayışla ikinci kuşak/çeper olarak algılanabilecek pozisyondaki devletlerle ilişkilerini geliştirmeyi hedeflemiştir. Bu açıdan bakıldığında, söz konusu benzeştirmenin olanakları ve kısıtları da ortaya çıkmaktadır.

Çevre(sel) Pakt olarak isimlendirilen politikanın temelinde, İsrail’i çevreleyen Arap devletlerinin dengelenmesi yatmaktadır. Bu çerçevede düşünüldüğünde, ilgili politikanın savunma merkezli bir yaklaşım olduğu görülebilir. Halbuki İsrail-Azerbaycan ilişkileri, İsrail merkezli bakıldığında, daha ziyade agresif bir nitelik sunar. Arap devletlerine kıyasla, İran'ın bulunduğu coğrafi konum ve elindeki imkanlar ölçüldüğünde, İsrailıe direkt ve ivedi bir tehdit olarak görülmesi, kurgusal nitelikler de barındırır. Ayrıca İran gibi görece uzak bir coğrafyada bir anlamda çevreleme politikası takip eden İsrail, aslında tehdit olarak algıladığı İran'ı sınırlandırmak amacındadır. Söz konusu nitelikleriyle birincil tehditler kategorisine girmesi zor gözüken İran, haliyle Çevre(sel) Pakt'ın hedeflediği beka merkezli politikaların kapsamından sıyrılır. Bu vakanın İsrail açısından savunma refleksleriyle kavramsallaştırılması, ancak "ileri savunma" gibi atak politikaları da çerçeveleyen bir tanıma ihtiyaç duymaktadır. Bu bağlamda denilebilir ki Çevre(sel) Pakt'ın kavramsal olarak ifade ettikleriyle, İsrail'in İran politikasının nitelikleri arasında kavramsallaştırma düzleminde ciddi sorunlar bulunmaktadır.

Söz konusu sorunsallaştırmaya istinaden bu çalışma, İsrail-Azerbaycan ilişkilerini farklı bir anlayışla ele alarak, analitik ve teorik bir çerçeveye oturtma amacını taşımaktadır. İlgili literatür incelendiğinde, iki devlet arasındaki ilişkilerin pek çok defa işlendiği ve fakat pratikte yaşananların teorik bir çerçeveye yerleştirilmekte zorlanıldığı gözlemlenebilmektedir. Bu bağlamda elinizdeki çalışma, İsrail-Azerbaycan ilişkilerine görece yeni bir perspektif ve dolayısıyla açıklama kapasitesi kazandırmayı hedeflemektedir. Söz konusu hedefini de Uluslararası

3 Orijinal versiyonuyla Çevre(sel) Pakt, İsrail dış politikasının 1950’li yıllarda Türkiye, İran ve Etiyopya’ya yönelik olarak kurguladığı ve uyguladığı bir politikayı ifade etmek için kullanılır (Bengio, 2004, s. 33-71). Bu bağlamda Azerbaycan, söz konusu politikanın bir parçası değildir. 
İlişkiler disiplininin iki temel yaklaşımıyla gerçekleştirmektedir. Tehdit dengesi teorisi ve analiz düzeyleri kullanılarak çerçevelenecek olan ilişkiler, iki devletin politikalarının berrak bir biçimde anlaşılabilmesini de sağlayacaktır.

\section{Teorik-Metodolojik Çerçeve}

Devletler, uluslararası politikada öncelikle ulusal güvenliklerini sağlayarak, hayatta kalabilmeyi hedeflerler. Uluslararası politikanın anarşik yapısı, devletleri, ulusal güvenliklerini sağlamak noktasında kendi başlarına bırakır. Bu durum da devletlerin, çeşitli yollardan ulusal güvenliklerini sağlamaya çalıştıkları süreçlerin önünü açar.

Söz konusu anarşik yapıda devletler, bağımsız birer ünite olarak, kendilerinden üstün bir otoriteye tabi olmadıklarından, yalnız başlarınadırlar (Mearsheimer, 2001, s. 3). Bu halde yapılabileceklerin bir sınırı vardır. Ulusal güvenlik politikalarına fazlasıyla yansıyan ölçülerde devletler; silahlanarak dengeleme ve hatta üstün bir konuma ulaşma, tehdit olarak algılanan devleti yatıştırma, tehdit olarak algılanan devletin taleplerine razı olma ya da söz konusu tehdit algılanan devleti yine tehdit olarak algılayan bir başka güçle işbirliği yaparak, tehdidi dengeleme stratejisi izlerler (Walt, 1987, s. 17-21) .

Stephen M. Walt'un geliştirdiği bir teori olarak tehdit dengesi, uluslararası politikanın uzun tarihinin ekseriyetle güçler dengesi kavramı çerçevesinde açılanmasına bir itiraz olarak şekillenir. Walt, uluslararası politikayı belirleyen devlet davranışlarının kökeninde güçlerin dengelenmesini değil, sivrilen tehditlerin dengelenmesini görür. Bu açıdan bakıldığında Walt’a göre tehdit olarak beliren devletin bir takım özellikler taşıyor olması gerekir. Toplam güç kapasitesi, coğrafi yakınlığı, saldırgan güç kapasitesi ve saldırgan niyetlerinin olması, bir devleti tehdit olarak tanımlamak için yeterlidir (Walt, 1987, s. 22-28).

Söz konusu tehdit, bir beka sorunu olarak algılanacağından, tehdidi algılayan devletin dış politika davranışlarını domine eder. Bu bağlamda tehdit algılayan devlet, ekseriyetle iki belirgin davranış kalıbı sergiler. Bunlar; dengeleme ve peşine takılma olarak gözlemlenir. Tehdit olarak sivrilen devlet, bir diğer devletle askeri işbirliğine gidilerek dengelenebilir. İkinci davranış kalıbındaysa tehdit algılayan devletin tehdit olarak gördüğü devletin peşine takılması ve bir biçimde beka sorununu aşması hedeflenir (Walt, 1985, s. 4-8).

Steven David'in tehdit dengesi teorisine katkısı, söz konusu dengeleme pratiğinin dâhili bir takım referanslara yönelik olabileceğini vurgulamaktadır (David, 1991, s. 233-256). Bu bağlamda David, bir devletin bir başka devletle güvenlik işbirliğine gitmesinin arkaplanında yönetici elitin ve hâlihazırdaki rejimin beka kaygılarının da önemli bir yer tuttuğunu öne çıkartır. Bir başka ifadeyle, rejim güvenliğinin devamlılığını sağlayabilmek adına, bir başka devletle ittifak ilişkisi geliştirilebileceğini söyler. David bu yaklaşımını, artık klişeleşmiş bir devletler 
kategorizasyonu olarak düşünüldüğünde, daha ziyade üçüncü dünya ülkelerine odaklanarak geliştirmiştir. Bu açıdan, Sovyet-sonrası bir rejim olarak Azerbaycan devleti ancak "ikinci dünya ülkesi” olarak sınıflandırllabilir. Günümüzde her ne kadar söz konusu üçlü tasnifin analitik bir anlamı kalmamışsa da David'in teorik katkısı, dünya politikasındaki pek çok dengeleme motivasyonunu açıklama kapasitesine sahiptir.

Bu çalışmanın kullanacağı bir başka metot olarak analiz düzeyleri ise uluslararası politikanın işleyişini kristalize bir netlikte ortaya koyabilmek aşamasında oldukça kritik bir rol oynar (Yurdusev, 2007-2008, s. 4-7). Bu bağlamda devletlerin dış politika oluşturma süreçleri, aslında birden fazla düzeydeki gelişmelerin baskılaması neticesinde ortaya çıkar. Bu düzeyleri ve bu düzeylere içkin gelişmeleri tasnif etmek ise ilgili devletin dış politikasını anlamlandırabilmek ve analitik bir biçimde ortaya koyabilmek açısından önemlidir (Temby, 2015, s. 721-742).

Analiz düzeyleri ekseninde yapılan tartışmalardan anlaşıldığı üzere, uluslararası politikanın değerlendirilmesi noktasında üzerinde tam anlamıyla konsensüs sağlanmış bir düzeyler silsilesi bulunmamaktadır. Bu bağlamda, ilk örneklerinin Kenneth N. Waltz'da göründüğünü ve üç ayrı düzeyden bahsedildiğini not etmek gerekmektedir. Waltz'un aynı zamanda doktora tezi olarak hazırladığı İnsan, Devlet ve Savaş: Teorik Bir Analiz isimli eseri, uluslararası politikanın ve savaşın analiz edilebilmesi için üç ayrı "imajdan” bahseder (Waltz, 2001). Waltz’a göre analiz seviyeleri; bireysel düzey, devlet yapıları düzeyi ve uluslararası anarşiden ibarettir. Bu üç analiz düzeyi, uluslararası çatışmaları ve dolayısıyla uluslararası politikanın işleyişini anlayabilmek noktasında kritik önemdedir. Waltz ile başlayan ve Uluslararası İlişkiler disiplinine davranışsalcı bir takım yenilikler getirmeyi önceleyen bu girişim, sonraları farklı yorumlarla zenginleşmiş ve analiz düzeyleri ve birimleri üzerine görece geniş bir literatür oluşmuştur (Temby, 2015, s. 723-728).

Bu bağlamda, analiz düzeyleri yaklaşımı İsrail-Azerbaycan ilişkileri özelinde düşünüldüğünde, ikili ilişkileri belirleyen üç temel düzeyden bahsetmek mümkün görünmektedir. Uluslararası, bölgesel ve ulusal düzeylerdeki parametreler, iki ülke ilişkilerinin yapısal çerçevesini oluşturmaktadırlar. Her üç düzeydeki gelişmeler, ikili ilişkileri yönlendirme kapasitesine sahiptirler. Bu noktadan bakıldığında, ikili ilişkilerin gerekçelendirilmesi ve anlamlandırılması, ancak kategorik bir analiz vasıtasıyla mümkün olabilir. Bu bağlamda, ikili ilişkilerin açıklanabilmesi için analiz düzeylerinin kullanılarak gelişmelerin tasnif edilmesi, bilimsel tutarlılığa sahip isabetli bir açıklama olasılığını güçlendirmektedir.

Ayrıca analiz düzeylerinin belirlenme süreçleri üzerinde de farklı tercihler söz konusu olabilmektedir (Buzan, 2015, s. 202-205). Bu çalışma yukarıda da anıldığı üzere; uluslararası, bölgesel ve ulusal düzey olmak üzere üç ayrı düzeyde analiz yapmayı hedeflemektedir. Uluslararası düzey kapsamında küresel güç dengeleri ve bu dengelerin iki ülke ilişkilerine etkisi; bölgesel düzey kapsamında, bölgesel güç dengelerinin ikili ilişkilere etkisi ve son olarak ulusal düzey kapsamında ise 
iki ülkenin ulusal sınırları içerisinde cereyan eden gelişmelerin ikili ilişkilere etkisi incelenecektir.

\section{İsrail'in Orta Asya Politikası}

İsrail-Azerbaycan ilişkilerinin incelenmesi, ancak İsrail'in Orta Asya'da Soğuk Savaş’ın bitişiyle birlikte bağımsızlıklarını kazanan Türk Cumhuriyetlerine yönelik perspektifi ile anlam kazanabilir. Bu çerçevede İsrail-Azerbaycan ilişkileri, genel bir çerçeve çizebilmek adına, İsrail'in Sovyet-sonrası bağımsızlıklarını kazanan ve Azerbaycan'ın da bir parçası olduğu Türk Cumhuriyetlerine dönük politikasını incelemekle yerli yerine oturtulabilir.

SSCB’nin dağılması ve Orta Asya'da bağımsız Türk Cumhuriyetlerinin kurulması, kuşkusuz öncelikle bir güç boşluğuna işaret etmiştir. Söz konusu güç boşluğu, Rus gücünün hinterlandı olarak algılanan bir coğrafyada ortaya çıkınca, haliyle Amerikan gücünün de ilgisini çekmiştir (Brzezinski, 1997, s. 30). Aşağlda da açıklanacağı üzere, Orta Asya'da ortaya çıkan yeni devletlerde Amerikan etkisinin arttırılması, dış politikasını bu çerçevede kalibre eden devletlerden biri olarak İsrail'in de amaçları arasına girmiştir. Bir başka ifadeyle İsrail, bölgeye yönelik ulusal çıkarlarını Amerikan çıkarlarıyla özdeşleştirerek, kendisine hayli geniş bir manevra sahası tesis etmiştir (Abadi, 2002, s. 69-71).

İsrail'in bölgeye yönelik ilgisi, elbette ki salt Amerikan çıarlarının realize edilmesiyle alakalı değildir. Bu bağlamda, bölgede yeni bağımsızlıklarını kazanan devletlerin hem ulusal bütünlüklerini korumaya hem ulusal liderlik kapasitelerini geliştirmeye hem de hızlı bir ekonomik kalkınmaya ihtiyaçları vardı (Abadi, 2002, s. 63-65). Bu açıdan bakıldığında, söz konusu devletler, hem dış ilişkilerinde hızlı bir diplomatik tanınma (recognition) pratiğine hem de yabancı devletlerle ekonomik ilişkilerini güçlendirmeye oldukça hazırdılar. Böylece İsrail, bölgede etkinlik kazanabileceği önemli gündem maddeleri elde etmiş oluyordu.

Ayrıca İsrail açısından da benzer bir fırsatlar dünyası ortaya çıkmıştı. Bu tarihlere kadar başat dış politik kaygısı olarak beliren geniş çaplı diplomatik tanınma pratiğini ilgili devletler nezdinde çözümlemek istiyordu. Orta Asya'da yeni ortaya çıkan bağımsız devletler eliyle diplomatik izolasyonunun kırılması, İsrail açısından önemli bir başlık olarak gözüküyordu (Abadi, 2002, s. 66). Ayrıca bölgenin sahip olduğu devasa enerji kaynakları, İsrail gibi enerji yoksunu bir ülke için kaçırılmayacak bir imkân sunuyordu. Enerjide dışa bağımlı profiline ek olarak, Arap boykotlarıyla da mücadele etmek durumunda olan İsrail açısından Orta Asya'da beliren enerji zengini yeni devletler, kuşkusuz enerji arz güvenliğini güçlendirebilecek faktörler olarak algılandılar (Bahgat, 2010, s. 410-411).

İsrail'i bölgeyle ilişkilerini güçlendirmek noktasında zorlayan bir başka konu başlığı ise söz konusu devletlerin, ekseriyetle Müslüman çoğunluklara sahip coğrafyalarda varlıklarını sürdürmekte olmalarıydı. Bu durum da haliyle, onlar açı- 
sından Arap devletleriyle ilişkilerini geliştirmeye uygun bir zemin yaratmaktaydı. Bu dönem için Filistin Sorunu'na destek vermeleri, yukarıda da anılan çerçeve doğrultusunda, Arap devletleriyle ilişkilerini geliştirmeleri ve ihtiyaç duydukları kaynaklara ulaşabilmeleri açısından elzemdi. 1992 yılı itibariyle bölge devletleri, peşi sıra Filistin Kurtuluş Örgütü'yle temas kurmaya başladılar (Aras, 1998, s. 69). Bu politik temaslar trendi, İsrail açısından nazik bir konu olması hasebiyle dikkat çekti ve buna mukabil İsrail, bölge devletleriyle yakınlaşmayı ve süreci dengelemeyi önceledi.

Bir başka boyutuyla Orta Asya Türk Cumhuriyetleri, radikal İslami hareketlerin genişlemesi ve güçlenmesi bağlamında da önemli birer saha işlevi yüklenebilirlerdi. Bu çerçevede İsrail, bölge devletleriyle ilişkilerini geliştirerek, Sovyet döneminden kalma politik-genetik bir kod olarak sekülerizmin güçlendirilmesini ve bu çerçevedeki lider/yönetim profillerinin sağlam bir biçimde yerleşmesini önemsedi (Abadi, 2002, s. 66). Böylece radikal akımların tesirine girmesi muhtemel bu coğrafyanın giderek İslami bir ton üzerinden kendini var eden Filistin direnişine insan kaynağı sağlamasını da engellemiş olmaktaydı.

Yukarıda anlatılanlar ölçüsünde İsrail, Orta Asya'da ortaya çıkan yeni devletlerle ilişkilerini geliştirmeyi önemsemiştir. Azerbaycan'ın da bir parçası olarak telakki edildiği coğrafyada, ilerleyen zamanlarda daha ziyade İran ve Rusya etkisinin sınırlandırılması noktasında da işlevsel bir anlam kazanan İsrail politikaları, ekseriyetle ABD tarafından da desteklenmiştir. Bu bölgesel çerçeveye istinaden İsrail-Azerbaycan ilişkilerini incelemek, ikili ilişkileri anlamlandırmaya dönük bir bilimsel çabanın isabet oranını yükseltecek bir yöntem olacaktır.

\section{İsrail-Azerbaycan İlişkilerinin Yapısal ve Analitik Çerçevesi}

İsrail-Azerbaycan ilişkileri, uluslararası politikanın diğer aktörleri gibi, yapısal birtakım kısıtlar ve imkanlarla örülmüş bir alanda cereyan etmektedir. Bu bağlamda bakıldığında, İsrail-Azerbaycan ilişkilerini yapısal düzleminden kopartarak incelemek, salt ikili ilişkilerde yaşanan gelişmelere indirgemek, sürecin tam anlamıyla kavranmasını ve bilimsel bir çerçevede analiz edilebilmesini engelleyebilecek bir tuzaktır. Bu mantıksal altyapıyla düşünüldüğünde, ikili ilişkilerin cereyan ettiği politik evreni keşfetmek ve yerli yerine konumlandırmak adına üç ayrı analiz düzeyinden faydalanmak, oldukça isabetli bir seçim olacaktır. İlerleyen alt başlıklarda da görülebileceği üzere, İsrail-Azerbaycan ilişkilerinin uluslararası, bölgesel ve ulusal düzeylerdeki imkanları ve kısıtlayıcıları, ikili ilişkilerin çerçevesini belirlemektedir.

\section{i. Uluslararası Bağlam}

Soğuk Savaş’ın sona ermesiyle birlikte çift kutuplu sıkı uluslararası sistem de ortadan kalkmış ve dünyanın hemen her noktasına uzun on yıllar boyunca sirayet 
etmiş olan süper güç rekabeti, yerini bölgesel ölçekli minimal rekabetlere bırakmıştır. Bu çerçevede, öncelikle Rus gücünün Soğuk Savaş süresince hâkimiyet tesis ettiği yakın çevresi, Amerikan stratejisi açısından kilit bir rol oynamıştır. Bu bağlamda da Güney Kafkasya'daki gelişmeler, iki kutuplu dönemdeki derecede bir sertliği barındırmasa da Amerikan-Rus çekişmesinin arenalarından biri haline gelmiştir (Markedonov ve Suchkov, 2020, s. 179-195). Rus gücünün eski ihtişamına kavuşmasını engellemeyi temel stratejik hedeflerinden biri haline getiren Amerikan yönetimleri, Sovyet-sonrası rejimlerle yakın işbirliği geliştirmeye ve onları politik, ekonomik ve askeri düzlemlerde desteklemeye gayret göstermiştir. Bu aşamada, Güney Kafkasya'da bağımsızlığını yeni kazanan bir cumhuriyet olarak Azerbaycan da söz konusu stratejik bakışın bir sonucu olarak, Amerikan ekseni çerçevesinde konumlandırılmaya çalışılmıştır. ${ }^{4}$

Azerbaycan dış politikası açısından bakıldığında, İsrail’le ilişkilerini geliştirmesinin uluslararası bağlamdaki başat getirisi, ekseriyetle Rus gücünün Amerikan gücüyle dengelenmesine zemin oluşturmasıdır (Pinfold ve Peters, 2021, s. 37). İsrail'in Amerikan yönetimi nezdinde özellikle de Yahudi lobisi vasıtasıyla elinde bulundurduğu politik güç, Rusya’nın Güney Kafkasya’daki müdahaleci potansiyelini kısıtlayabilmek adına, oldukça işlevsel bir kapasite sunmaktadır.

Soğuk Savaş’ın bitişiyle birlikte bağımsızlığını kazanan Azerbaycan, 25 Aralık 1991 itibariyle İsrail tarafından diplomatik olarak tanınmıştır. Bu hamleye hızlı bir biçimde karşılık vererek ve bu tarihlerde Dağlık Karabağ' daki çatışmalarda elini güçlendirebilmek adına, Azerbaycan da İsrail’i Nisan 1992 itibariyle diplomatik olarak tanımış ve ilişkilerini resmi düzeyde başlatmıştır (Murinson, 2014, s. 10). Bu çerçevede İsrail, zaman kaybetmeksizin 1993 yılı içerisinde Bakü’de diplomatik temsilciliğini açarak, yeni bağımsızlığını kazanan devletle temas noktası oluşturmuştur. Lakin Azerbaycan, İsrail'de bir diplomatik temsilcilik açmamış ve bunun yerine, Azerbaycan Havayolları'nın Tel Aviv'de bulunan ofisini gayri resmi olarak kullanmayı tercih etmiştir (Lindenstrauss, 2015, s. 70). Bu hamlesiyle Azerbaycan, özellikle de İran rejiminin kışkırtmalarıyla İslam dünyasından gelebilecek eleştirileri engellemeyi hedeflemiş gözükmektedir.

Söz konusu hızlı diplomatik tanıma pratiği, Azerbaycan açısından, hem yeni bağımsızlığını kazanan devletin varlığını tasdik ettirme hem de olası Rus müdahaleciliğini bölgesel düzeyde sınırlandırma potansiyeli taşımaktadır. Kaldı ki bu pratik, Amerikan yönetiminin bölgeye bakışına da gayet uyumlu bir hamle olarak gözükmektedir.

Bu tarihler itibariyle, Güney Kafkasya'da yeniden Rus hegemonyasının tesis edilebilme ihtimali ya da aşırıcı hareketlerin bu bölgede istikrarsızlığı yaygınlaş-

\footnotetext{
4 ABD Kongresi’nin 2532 sayılı “Özgürlüklere Destek Yasası”, Sovyet-sonrası ülkelerin desteklenmesini hedeflemekteydi. Bu minvalde, Azerbaycan da potansiyel bir muhatap olarak belirmişti. Lakin Ermeni lobilerinin yoğun tesiriyle, söz konusu yasanın ilgi alanından Azerbaycan çıkartılmıştır. Bu durum, Azerbaycan açısından İsrail'le ilişkilerini geliştirmenin ve ABD'deki Yahudi lobisinin nüfuzunu kullanabilme imkanına ulaşabilmenin gerekliliğini göstermiştir (Özdaşlı ve Kodaman, 2016, s. 122).
} 
tırma olasılıkları, Amerikan yönetiminin Azerbaycan gibi seküler devlet yapılarını desteklemesine vesile olmuştur. İsrail'in Azerbaycan'la geliştirdiği ilişkiler, temelde hem tarihsel olarak yeniden iddia sahibi bir görünüm elde edebilecek olan Rus gücünü hem de aşırıcı hareketler üzerinden manevra kabiliyeti kazanabilecek olan İran rejimini sınırlandırmanın anti-tezini oluşturmaktadır (Murinson, 2014, s. 10).

Ayrıca Azerbaycan, Dağlık Karabağ'ın işgal edilmesi sebebiyle sorun yaşadığı Ermenistan'ın ABD'deki lobi gücünü de dengelemeye çalışmıştır. Bu bağlamda Azerbaycan'ın İsrail'le geliştirdiği ilişkileri, Yahudi lobisinin etki kapasitesi sayesinde kendisine Amerikan siyaset çevrelerinde güçlü bir destek sağlamış ve Ermeni lobisinin Azerbaycan aleyhine yürüttüğü çalışmalara ket vurmuştur (Murinson, 2014, s. 20-21). Azerbaycan-İsrail ilişkilerindeki stratejik yakınlaşmanın önemli bir boyutu, kuşkusuz, Azerbaycan'ın ulusal güvenlik kaygıları çerçevesinde şekillenmiştir.

İsrail-Azerbaycan yakınlaşması, 1990'lı yıllar itibariyle bölgesel düzlemde tesis edilmeye çalışılan İsrail-Azerbaycan-Türkiye-Gürcistan aksının da bir parçası olarak telakki edilebilir. Bu çerçevede, 1996 yılında İsrail ile Türkiye arasında askeri bir işbirliği anlaşması imza edilmiş, Hazar Denizi'ndeki Azerbaycan petrolü Bakü-Tiflis-Ceyhan boru hattı projesiyle işlevselleştirilmiş ve böylece söz konusu yakınlaşma, bölgesel ölçekli pax-Americana'nın dört ayaklı güçlendirilmiş bir sütunu olarak gündeme gelmiştir. Böylece Suriye-İran-ErmenistanRusya dörtlüsünün oluşturduğu karşı bloğun dengelenmesi de mümkün olmaktadır (Lindenstrauss, 2015, s. 73).

Türkiye ile İsrail arasında 1996 yllında imzalanan askeri işbirliği anlaşmasından kısa bir süre sonra, 29 Ağustos 1997'de dönemin İsrail Başbakanı Binyamin Netanyahu Bakü'ye kısa bir ziyaret gerçekleştirmiştir. Bu tarihlerde Azerbaycan Devlet Başkanı Haydar Aliyev'le yapılan görüşmelerde, iki ülke arasında enerji, iletişim, bilim vb. konularda yapılabilecek işbirlikleri değerlendirilmiştir (Murinson, 2014, s. 15). Söz konusu ziyaretin zamanlaması, Azerbaycan'ın, Türkiye ile varılan anlaşmanın tamamlayıcı unsuru olarak görüldüğüne de işaret etmektedir. Bu ilk ziyaretten sonra da İsrailli devlet yetkililerinin çok defa Azerbaycan'a gittikleri bilinmektedir.

İsrail açısından bakıldığında, Azerbaycan'la ilişkilerini geliştirmenin uluslararası bağlam çerçevesinde birkaç önemli başlığı bulunmaktadır. Bunlardan ilki, İsrail'in nüfusu çoğunlukla Müslüman olan bir ülkeyle ilişkilerini geliştirerek, İsrail-Filistin meselesinden mülhem Yahudi-Müslüman dikotomisini boşa çıkarmaya çalışmasıdır. Bu bağlamda, İsrail-Azerbaycan ilişkilerinin gelişmesi hem İsrail’in dünya üzerindeki Müslüman kitlelere yönelik güçlü bir mesajını taşımaktadır hem de uluslararası kabulünü arttırması noktasında işlevseldir (Özdaşlı, 2017, s. 181).

Ayrıca Azerbaycan'ın mezhebi yönden Şii Müslüman bir kitleye sahip olması, İsrail-İran rekabetinde İsrail'in elini güçlendirebilecek bir olgu olarak görülmeli- 
dir. Benzer şekilde ağırlıklı bir Şii Müslüman kitleye yaslanması ve teokratik rejimini de Şii mezhebinin anlatısı doğrultusunda konfigüre etmiş olması hasebiyle İran, İsrail-Azerbaycan ilişkilerinin barış̧̧l bir atmosferde yürütülebilmesi sayesinde, İsrail'in sahip olduğu Yahudi kimliğini ve devletin Siyonist yapısını makro düzeyde güvenlikleştirebilme yetilerinden mahrum kalmaktadır. Bir diğer ifadeyle, İsrail'in Azerbaycan özelinde ağırlıkla Şii Müslüman nüfusa sahip bir devletle kurabildiği stratejik ilişkiler, İran’ın İsrail dış politikasına yönelik üretebileceği "Müslüman karşıtlığı" temelli kategorik bir zemini daha başından engellemektedir. Bu açılardan düşünüldüğünde, İsrail-Azerbaycan ilişkilerinin gelişim seviyesi, İsrail dış politikasının İslam dünyası özelinde ve hatta uluslararası bağlamı çerçevesinde de oldukça kıymetli bir konuma sahiptir. (İsmayilov, 2013, s. 70)

\section{ii. Bölgesel Bağlam}

Soğuk Savaş sonrası dönemin belirleyici bir özelliği, yukarıda da anıldığı üzere, bölgesel rekabetleri su üstüne çıkarmış olmasıdır. Bu bağlamda, yeni bağımsızlığını kazanan Azerbaycan'ın sahip olduğu nitelikler ve teritoryal imkânlar, aynı zamanda sınır komşuları olan rakip devletlerin bölgesel projeksiyonlarını gerçekleştirebilmeleri adına, ulaşılması ve etki altına alınması gereken bir hedef haline gelmiştir. Dağlık Karabağ'ın Ermenistan tarafından işgal edilmesi ve İran'ın bu gelişmeyi desteklemesi, bölgesel rekabetlerin açık bir savaş haline sebep olabileceğine delalet etmiştir.

Bağımsızlığını kazandığı tarihten bu yana İsrail, ulusal güvenliğini başat bir biçimde dış politikasına yansıtmış bir ülkedir. Bu bağlamda, özellikle Yahudilerin kadim tarihinde yaşanan olumsuzluklar, İsrail devletinin ulusal güvenlik pratiklerine yönelik net bir referans noktası oluşturmaktadır. Yaklaşık üç çeyrek asırlık bir devlet ömrüne sahip olmasına rağmen, günümüzde dahi varoluşsal ulusal güvenlik tehdidi algılamalarının İsrail dış politikasına hâkim olması, hususiyetle İran tehdidinin nükleer bir zeminde gelişmesiyle paralel ilerlemektedir (Baghat, 2006, s. 307-327) .

1979'daki İran İslam Devrimi’nden bu yana İsrail, hem söz konusu devrimin köktenci niteliği hem de kendisini direkt olarak hedef almasından dolayı, İran’ı ulusal güvenlik ajandasında üst sıralara taşımıştı. Ayrıca devrimle birlikte İslami hassasiyetlerden ötürü kesintiye uğrayan İran'ın nükleerleşme süreci, İranIrak savaşındaki olumsuz tecrübeler ve özellikle de caydırıcılık kapasitesinden yoksunluğu sebebiyle yeniden canlandırıldığında, İsrail açısından algıladığı tehdidin kapasitesi de büyümüştür. Bu bağlamda denilebilir ki İsrail ulusal güvenlik gündeminin başat maddesini İran'ın nükleerleşmesi oluşturmaktadır (Freilich, 2018, s. 83-85).

Günümüzde ise hem Arap Baharı hem de 2015 yılında imza edilen Nükleer Anlaşma (JCPoA) vesileleriyle İran'ın elde ettiği bölgesel nüfuz, İsrail siyasi ve güvenlik elitlerinin dikkatle izledikleri bir süreç olarak görülmektedir. Lübnan’ın 
güneyinde bulunan Hizbullah'ın Suriye iç savaşı süresince İran'la koordinasyon halinde sahaya inmesi, İsrail ulusal güvenlik algıları açısından oldukça önemli bir kırılma noktası olarak işaretlenebilir. Ayrıca Suriye ve Yemen'deki iç savaşları süresince elde ettiği etki kapasitesi, İran'ın bölgesel düzeyde bir tehdit olarak da algılanmasını pekiştirmektedir. Böylece İran, İsrail ulusal güvenlik düşüncesinin merkezi bir referansı olarak kavranmakta ve nüfuzu altında tuttuğu vekilleriyle İsrail'i tehdit etmektedir (Freilich, 2018, s. 73-79).

Azerbaycan ulusal güvenliği açısından da İran'ın benzer bir konumu söz konusudur. Sahip olduğu nitelikler itibariyle İran, Azerbaycan açısından da önemli bir tehdit kaynağı olarak belirmektedir. Özellikle Dağlık Karabağ'ın işgal edilmesi ve devam eden süreçte İran, Ermenistan'a yakın durmuş ve böylece Azerbaycan'ı dengelemeye çalışmıştır.

Soğuk Savaş sonrası dönemde bağımsızlığını kazanan iki Sovyet-sonrası devlet olarak Azerbaycan ve Ermenistan, Güney Kafkasya'da dengelerin dönüşümüne sebep olacak bir rekabet halindedirler. Bu rekabetin tarafları, aynı zamanda yakın çevrelerinden edindikleri müttefikleriyle rekabetteki dengeyi korumaya çalışmışlardır. Bu bağlamda, Türkiye-Azerbaycan ikilisine karşılık olarak İran da Ermenistan’ı desteklemektedir. Söz konusu işbirliğinin İran açısından rasyonalitesi, Türkiye'nin politik açıdan istikrarlı bir Azerbaycan'la süreklilik arz eden bir temas kurup, Orta Asya coğrafyasında da etkin bir aktör olarak belirmesi ihtimaline ket vurabilmeyi hedeflemektedir (Olson, 2002, s. 61-85). Bu bağlamda söz konusu iki Türk devleti, İran'ın bölgesel nüfuzuna set çekebilecek kapasiteye sahip olduklarından ötürü, İran ulusal güvenlik düşüncesi çerçevesinde tehdit kaynağı olarak görülmektedirler. Nihayetinde söz konusu ilişkiler, İran’ın ulusal güvenlik değerlendirmelerinde üst sıralarda yer tutmaktadır.

İsrail ile Azerbaycan'ın yakınlaşmasının altyapısında, Azerbaycan'ın taşıdığı nitelikler de önem arz etmektedir. Bu açıdan yaklaşıldığında, Şii ağırlıklı bir nüfusa sahip olması ve İran sınırları içerisinde bulunan ve Güney Azerbaycan olarak da bilinen bölgede İran nüfusunun yaklaşık olarak 1/5'nin Azerbaycan Türk'ü olması, Azerbaycan'ın stratejik önemini arttırmaktadır. Bu nitelikleriyle Azerbaycan, İran'ın teritoryal bütünlüğünü ve dolayısıyla istikrarını etkileme kapasitesine güçlü bir biçimde sahiptir (Souleimanov ve Ditrych, 2007, s. 103).

Şii ağırlıklı bir nüfusa sahip olmasıyla Azerbaycan, hem İsrail'in Müslüman bir müttefiği olarak konumlanmakta hem de İran'daki rejime istinaden, İsrail'in "aslında Şii kitlelerle herhangi bir sorunu bulunmadığını" ispatlamaktadır. ${ }^{5}$ İsrail dış politikasının neredeyse bütün bir tarihine hükmeden Çevre(sel) Pakt, İsrail'i çevreleyen Arap devletlerinin izolasyonunu aşma pratiği olarak görüldüğünde, Azerbaycan'ın Şii Müslüman kimliği oldukça önem kazanmaktadır (Murinson, 2014, s. 12).

\footnotetext{
5 Ayrıca son yıllarda gelişim gösteren Suudi Arabistan-Azerbaycan ilişkileri de İsrail-Azerbaycan ilişkilerinin bir parçası olarak düşünülebilir. Bu çerçevede Azerbaycan'da İran merkezli Şii etkisine karşı Sünni etkisinin arttığı da gözlemlenen bir husustur (Grebennikov, 2015, s. 431-432).
} 
Ayrıca Azerbaycan açısından birincil bir tehdit kaynağı olarak görülen Ermenistan, Dağlık Karabağ’ı işgal ederek, bu bölgeyi uzun yıllar boyunca hâkimiyeti altında tutmuş ve Azerbaycan'ın teritoryal bütünlüğüne zarar vermiştir. Özellikle 1992 yılındaki Birinci Dağlık Karabağ savaşında Azerbaycan kuvvetleri, Ermeni kuvvetleri karşısından tutunamamış ve bölgeden çekilmek zorunda kalmışlardır. Söz konusu savaşla birlikte ortaya çıkan durum, bu noktada belirtilmesi elzem bir husus olarak, Azerbaycan kuvvetlerinin savaş kapasitesi ve silah envanterinin görece yetersiz kaldığını göstermektedir. Bu dönemde Türkiye'nin Azerbaycan’a askeri yardımları da yeterli olmamış ve Dağlık Karabağ bölgesi Ermeni kuvvetleri tarafından işgal edilebilmiştir.

Azerbaycan'ın yukarıda anlatılanlar çerçevesinde düşünüldüğünde, silah tedarik kanallarını çeşitlendirmesi ve bu süreçleri güvenceye alması önemli bir dış politika hedefi olarak görülmelidir. Azerbaycan ulusal güvenliği açısından İsrail’in oynadığı stratejik rol, özellikle de silah satışları kapsamında düşünülmelidir. Kaldı ki İsrail, Birinci Dağlık Karabağ savaşından sonra güçlü bir biçimde Azerbaycan'ı desteklemiş ve silahlanmasına yardımcı olmuştur. İsrail'in sahip olduğu gelişmiş askeri teknoloji ürünü silahlar, İsrailli firmalar aracılığıyla Azerbaycan’a teslim edilmiş ve bu süreç günümüze kadar devam etmiştir. İkinci Dağlık Karabağ savaşı esnasında da görüldüğü üzere Azerbaycan kuvvetleri, özellikle de İsrail menşeili silah stoğunun verdiği teknolojik üstünlüğe yaslanarak, önemli bir avantaj elde etmiştir (Rod, 2020).

Söz konusu silah ticareti uzun yıllardır devam etmektedir. Hatta öyle ki Azerbaycan henüz bağımsızlığını kazanmamışken de İsrail'den silah satın almış ve bağımsızlığını kazandığı 1991 yılından sonra da bu ticaret giderek artan bir ivme yakalamıştır. Bu bağlamda, 2008 ve 2012 yıllarında yapılan silah ticaretinin İran açısından da önemli sonuçları olduğu görülmektedir. Özellikle de 2012 yılında yapılan ve 1.6 milyar dolar tutarındaki silah ticareti anlaşmasının hacmi, ikili ilişkilerin stratejik düzeyini göstermesi açısından da önemlidir (Haaretz, 2012).

Ayrıca Azerbaycan'ın İran'la sınırdaş coğrafyası, İsrail açısından birtakım avantajlar doğurmakla birlikte, Azerbaycan ulusal güvenliğine yönelik tehditleri de köpürtmektedir. Bir örnek olması hasebiyle, söz konusu silah ticaretinin de bir parçası olarak düşünülmesi kaydıyla, İran nükleer tesislerinin bulunduğu Natanz kenti üzerinde düşürülen insansız hava aracının Azerbaycan’dan kalktığı İranlı yetkililer tarafından belirtilmiş ve Azerbaycan, İran tehditlerine hedef olmuştur (AP News, 2014). Ayrıca bu gelişmeden de anlaşılabileceği üzere Azerbaycan'dan kalkan insansız hava araçlarının İran'a karşı istihbari amaçlarla kullanıldığını da not etmek gerekmektedir.

Bu çerçevede, 2021 yılının sonbaharı itibariyle, İran'ın Azerbaycan sınırında yapacağı tatbikata verdiği isim de bu açıdan oldukça manidardır (Hürriyet, 2021). Tatbikata "Hayber" isminin verilmesi, İslam tarihindeki Yahudilerle yapılan mücadeleyi anımsatması çerçevesinde oldukça stratejik bir rol üstlenmektedir. $\mathrm{Bu}$ durum da göstermektedir ki İran, Azerbaycan'ın İsrail'le ilişkilerini tehdit edici 
bulmakta ve Azerbaycan'ı kimliksel bir düzlemde İsrail ile eşitleyerek ve ötekileştirerek, hasmane politikalar kurgulayabilmektedir.

Son olarak, İsrail açısından bakıldığında enerji güvenliği ve bu konu özelinde Arap-İran etkisinin kısıtlanması da önemli bir faktör olarak görülebilir. ${ }^{6} \mathrm{Bu}$ bağlamda İsrail, petrol ihtiyacının yaklaşık olarak \%40'ını karşılayan Azerbaycan'ı önemli bir enerji tedarikçisi olarak algılamaktadır. Azerbaycan’a enerji güvenliği çerçevesinde verilen önem, özellikle de 1973 yılında yaşanan petrol krizi sebebiyle stratejik bir boyuttadır. Goldenstein'a göre bu krizden aldığı derslerle İsrail, enerji sektöründe Arap-İran etkisini dengeleyebilmek adına, Azerbaycan petrolünü işlevsel bulmaktadır (Goldenstein, 2020).

\section{iii. Ulusal Bağlam}

Azerbaycan-İsrail ilişkilerini analiz ederken ulusal düzeyde politik istikrarı etkileyebilecek hususlardan bahsedilmediği takdirde etraflıca ve isabetli bir değerlendirmeden uzaklaşılabilir. Her iki devletin ulusal ölçekteki bazı parametreleri, ikili ilişkileri kolaylaştırmanın birer fonksiyonudurlar. Bu bağlamda İsrail, Azerbaycan’ın rejim güvenliğinin ve dolayısıyla ulusal güvenliğinin de önemli bir destekçisi konumundadır. Ayrıca İsrail'deki Azerbaycan Yahudilerinin varlığı da hem diaspora etkisi doğurmakta hem de bu durumla ilintili olarak, ülkenin seçmen nüfusu bağlamında görece önemli bir politik baskı unsuru yaratmaktadır.

Pollock'a göre, Azerbaycan ile İsrail arasındaki ilişkilerin detaylarına odaklanıldığında, özellikle istihbarat ve siber güvenlik alanındaki alışverişin düzeyi, Azerbaycan'ın ulusal güvenliğini belirli bir seviyede idame ettirebilmesi adına oldukça kritik önemdedir (Pollock, 2020). Bu aşamada, Azerbaycan'ın ağırlıklı olarak Şii Müslüman bir nüfusa sahip olması, İran'ın etki kapasitesini genişletebilecek bir olgu olarak belirmektedir. Bir diğer ifadeyle Azerbaycan, ulusal kimliğinin ekseriyetle Şii Müslüman bir aksa oturmasından dolayı, Şii Müslüman kitlelere hamilik rolünü sıklıkla gündeme getiren İran rejiminin hedefi olabilmektedir. Bu sebeple de Azerbaycan'ın İsrail'le olan ilişkilerine atfettiği önem, oldukça kritik bir seviyededir. Nihayetinde İsrail, İran'ın Azerbaycan nüfusunun mezhebi kimliğine hitap ederek, ülkeyi olası bir istikrarsızlığa sürüklemesinin önüne geçebilecek bir müttefik olarak algılanmaktadır.

Azerbaycan'ın İran'dan algıladığı bir başka tehdit düzeyi ise direkt olarak rejimin güvenliği ile alakalıdır. Azerbaycan'daki kurulu düzen, seküler bir çizgiye sahip olmakla birlikte, Batıcı bir profil de sunmaktadır. Fakat İran rejimi, İslam devriminden bu yana teokratik sistemini ihraç etme çabası içerisinde olduğundan ve Azerbaycan nüfusunun nitelikleri de söz konusu rejim ihracı politikasının hedeflediği kitlelere uygun düştüğünden, rejimin seküler kimliği başlı başına bir hedef haline gelebilmektedir. Ayrıca Azerbaycan'ın öncesinde de açıklandığı üze-

6 İsrail-Azerbaycan ilişkilerinin ekseriyetle enerji güvenliği çerçevesinde değerlendirilmesi gereğini iddia eden çalışmalar da literatürde yer almaktadır (Göksel, 2015). 
re çeşitli sistemik-bölgesel dengelemelerin bir unsuru olarak Amerikan gücüyle yakınlaşması, Azerbaycan rejiminin İran'ın gözünde açık bir tehdit kaynağı olarak kodlanmasına imkân vermektedir.

İsrail açısından bakıldığında ise Azerbaycan'la ilişkilerinin ulusal düzeydeki en belirgin yansıması, Azerbaycan Yahudilerinin İsrail'deki sosyo-politik ve sosyo-ekonomik konumları üzerinden tanımlanabilmektedir. $\mathrm{Bu}$ bağlamda irdelendiğinde, özellikle İkinci Dağlık Karabağ Savaşı süresince İsrail'deki Azerbaycan Yahudilerinin yoğun bir biçimde Azerbaycan yönetimini destekledikleri görülmektedir (The Jerusalem Post, 2020).

Çeşitli gösteriler yoluyla Azerbaycan'a verdikleri desteği ifade eden kitleler, İsrail gibi görece kısıtlı bir demografiye sahip bir ülkede haliyle önemli bir siyasi güç odağı olarak görülmektedirler. Siyasi sistemi itibariyle küçük partilerin dar marjlarla parlamentoda ve hükümet kompozisyonlarında etkinlik kazanabildiği bir devlet yapılanmasına sahip olan İsrail'de siyasi partiler, haliyle, Azerbaycan'dan göç etmiş Yahudi kitlelere karşı da kayıtsız kalamamaktadırlar. Bu çerçevede bakıldığında, Azerbaycan Yahudilerinin kurumsal bir kimlik kazanmaları ve bu kimlik etrafında örgütlenmeleri de kendilerini siyasi bir güç olarak hissettirmektedir (Azerbaijan State News Agency, 2007).

Ayrıca Azerbaycan'da yaşayan Yahudi azınlığı da önemli bir faktör olarak görülmelidir. Azerbaycan Yahudileri, tarihsel olarak Sovyetik rejimlerde olmadığı derecede özgürlükçü bir atmosferden istifade etmişler ve bu durum da Azerbaycan ile İsrail'in yakınlaşmalarını ve stratejik ilişkiler kurgulamalarını kolaylaştıran bir etken olarak görülmüştür (Özdaşlı ve Kodaman, 2016, s. 113-115). İsrailli ve Azerbaycanlı yetkililerin çok defa ifadeleriyle teyit edilen bir olgu olarak antisemitizmin Azerbaycan'da zemin bulamaması, kuşkusuz İsrailli siyasi elitlerin de özellikle önem verdikleri bir husustur. Her ne kadar bazı dönemlerde buradaki Yahudi varlığının İran karşıtı istihbari eylemlerde kullanılmasına yönelik bir takım fikirler ortaya çıksa da İsrail yönetimleri ekseriyetle Azerbaycan'daki barış̧̧ıl ve hoşgörülü toplumsal atmosferi desteklemektedir (Bourtman, 2006, s. 55).

\section{Sonuç}

İkinci Dağlık Karabağ savaşı esnasında Ermenistan destekçilerinin çeşitli vesilelerle belirttikleri argümanlar, İsrail'in artık Azerbaycan'ı desteklemek zorunda olmadığı yönünde bir mantıksal güzergah izlemektedir (Galitsky, 2020). Özellikle İbrahim Anlaşması'nın İsrail dış ve ulusal güvenlik politikaları açısından oldukça stratejik bir kazanım olduğu ve İran'ı dengelemek noktasında Azerbaycan'a ihtiyacının kalmadığı iddia edilmektedir. Bu bağlamda da İsrail-Azerbaycan ilişkilerinin temel rasyonalitesini kaybettiğini vurgulayarak, iki ülke ilişkilerinin Ermenistan lehine bir gerileme yaşamasını umut etmektedirler. ${ }^{7}$

\footnotetext{
Her ne kadar bu minvalde beklentiler söz konusu olsa da İsrail-Azerbaycan ilişkilerinin özellikle askeri sektördeki işbirliği olanca hızıyla sürmektedir (Mehdiyev, 2021).
} 
İsrail-Azerbaycan ilişkilerinin temeli, yukarıda da incelendiği üzere, uluslararası, bölgesel ve ulusal bağlamlarda tehditleri dengelemek üzerine kuruludur. Bu bağlamda bakıldığında, iki ülke ilişkilerinin salt İran'ı dengelemekten ibaret bir hedefleri bulunmamaktadır. Bölgesel düzeyde İran'ı dengelemenin yanında, uluslararası düzeyde açıklanabilecek ölçülerde, Rus gücünün bölgede etkinlik kazanmasını engellemek de iki ülke ilişkilerinde katalizör rolü oynamaktadır. Ayrıca ulusal düzeyde de Aliyev yönetiminin seküler rejiminin güvenliğini sağlama noktasında İsrailıe ihtiyacı olduğunu da belirtmek gerekmektedir. Buna karşılık olarak da İsrail iç siyaseti, Azerbaycan〉dan İsrail'e göç etmiş Azerbaycan Yahudilerini hesaba katmak durumundadır.

İkinci Karabağ Savaşı'nın Azerbaycan'ın açık üstünlüğüyle sona ermesi, İsrail-Azerbaycan ilişkileri açısından da oldukça önemli birtakım sonuçlara yol açmıştır. Bu bağlamda bakıldığında, Dağlık Karabağ bölgesinin Azerbaycan tarafından geri kazanılması, özellikle İran'ın kuzey sınırlarında neredeyse kesintisiz bir Azerbaycan varlığına sebep olmuştur. Böylece Azerbaycan, İran'ın kuzeyinden çevrelenmesini sağlayacak ölçülerde Ermenistan'la karasal iletişimini sınırlandırmış ve İsrail stratejisi açısından kritik önemde bir kazanım sağlamışırı. Söz konusu alanın denetimi, İran'ın Ermenistan'la gerçekleştirdiği alışverişin takip edilebildiği bir zemin yaratmıştır.

Bir diğer kazanım olarak görülebilecek olgu ise Türkiye-Azerbaycan hattının kesintisiz bir hal almasıdır. Bu durum, Türkiye açısından oldukça stratejik bir kazanım olarak görülebilir. Türk dünyasıyla politik-ekonomik iletişimini güçlendireceği muhakkak olan bu koridor, Türkiye-İran ilişkilerinde stratejik bir konuda Türk tarafının elini rahatlatacaktır. Aynı zamanda hem Azerbaycan hem de Türkiye açısından, Çin'in doğu-batı hattında kurguladığı Tek Kuşak Tek Yol projesi kapsamında da avantajlı bir statü elde edileceği ortadadır (Rehimov, 2021). Bu gelişme, kuşkusuz Türkiye-Azerbaycan-İsrail üçlüsü arasında da çeşitli iletişim kanallarının oluşmasına ve var olanların da güçlenmesine vesile olabilir.

$\mathrm{Bu}$ çalışmanın ulaştığı sonuçlar itibariyle İsrail-Azerbaycan ilişkilerinin; uluslararası, bölgesel ve ulusal düzeylerde beliren tehditleri dengelemek üzerine kurulduğu görülmektedir. Bu bağlamda Rusya ve İran'ın çeşitli düzeylerde edindikleri konumlar, İsrail-Azerbaycan arasındaki ikili ilişkilere hem yapısal hem de analitik bir açıklama kapasitesi getirilmesini kolaylaştırmaktadır. Nihayetinde İsrail-Azerbaycan ilişkilerinin yapısal ve analitik bir çerçevede anlaşılması, Türkiye'nin özellikle de İsrailıe yönelik kurgulayacağı politikaları açısından, imkanlarını geliştirebilecek bir nitelik de sunabilir. 


\section{Kaynakça}

Abadi, J. (2002). Israel's Quest for normalizationn with Azerbaijan and the Muslim States of Central Asia. Journal of Third World Studies, 19(2), s. 63-88.

AP News (2014). Iran says Purported Drone Came from North. https://apnews.com/ article/954853728f5f4580b761321ca9ac94c0 (E.T. 19.05.2021).

Aras, B. (1998). Post-Cold War Realities: Israel's Strategy in Azerbaijan and Central Asia. Middle East Policy, 5, (4), s. 68-81.

Azerbaijan State News Agency (2007). Azerbaijan-Israel International Association Founded. https://azertag.az/en/xeber/AZERBAIJAN_ISRAEL_INTERNATIONAL_ ASSOCIATION_FOUNDED-565963 (E.T. 20.05.2021).

Bahgat, G. (2006). Nuclear Proliferation: The Islamic republic of Iran. Iranian Studies, 39(3), s. 307-327.

Bahgat, G. (2010). Israel's Energy Security: The Caspian Sea and The Middle East. Israel Affairs, 16 (3), s. 406-415.

Bengio, O. (2004). The Turkish-Israeli Relationship: Changing Ties of Middle Eastern Outsiders. New York: Palgrave Macmillan.

Bourtman, I. (2006). Israel and Azerbaijan’s Furtive Embrace. Middle East Quarterly, s. 47-57.

Brzezinski, Z. (1997). The Grand Chessboard: American Primacy and its Geostrategic Imperatives. Basic Books.

Buzan, B. (2015). Uluslararası İlişkilerde Analiz Düzeyi Sorununu Yeniden Düşünmek, K. Booth ve S. Smith (eds.), Uluslararası İlişkiler Kuramları içinde (s. 198-217). Muhammed Aydın (Çev.), İstanbul:Röle Akademik Yayıncılık.

David, S.R. (1991). Explaining Third World Alignment. World Politics, 43(2), s. 233-256.

Freilich, C.D. (2018). Israeli National Security: A New Strategy for an Era of Change. New York:Oxford University Press.

Galitsky, A. (2020). Israel should Rethink its Relationship with Azerbaijan. The Jerusalem Post. https://www.jpost.com/opinion/azerbaijan-is-not-a-true-friend-of-israel-635729 (E.T. 07.08.2021).

Goldenstein, A. (2020). Why Israel does not Need to Rethink its Relationship with Azerbaijan. The Jerusalem Post. https://www.jpost.com/opinion/why-israel-does-notneed-to-rethink-its-relationship-with-azerbaijan-637151 (E.T. 25.05.2021).

Göksel, O. (2015). Beyond Countering Iran: A Political Economy of Azerbaijan-Israel Relations. British Journal of Middle East Studies, 42(4), s. 655-675.

Grebennikov, M. (2015). Skating on Thin Ice: Israel's Strategic Partnership with Azerbaijan in the South Caucasus. Israel Journal of Foreign Affairs, 9(3), s. 429-439.

Guzansky, Y. (2014). Israel's Periphery Doctrine 2.0: The Mediterranean Plus. Mediterranean Politics, 19(1), s. 99-116.

Haaretz. (2012). Israel Signs 1.6 Billion Arms Deal with Azerbaijan. https://www.haaretz. com/1.5190757 (E.T. 24.05.2021).

Hürriyet. (2021). Azerbaycan-İran Sınırında Tatbikat Gerginliği. https://www.hurriyet.com. tr/dunya/azerbaycan-iran-sinirinda-tatbikat-gerginligi-41906953 (E.T. 01.10.2021).

Irish, J., Rose, M. ( 2020). France Accuses Turkey of Sending Syrian Jihadists to NagornoKarabakh. Reuters. https://www.reuters.com/article/us-armenia-azerbaijan-putinmacron-idUSKBN26L3SB (E.T. 24.05.2021). 
Ismayilov, E. (2013). Israel and Azerbaijan: The Evolution of a Strategic Partnership. Israel Journal of Foreign Affairs, 7(1), s. 69-76.

Katz, Y. (2020). Armenian FM to 'Post': Israel Needs to Halt All Weapon Sales to Azerbaijan. The Jerusalem Post. https:/www.jpost.com/israel-news/armenian-fm-topost-israel-needs-to-halt-all-weapon-sales-to-azerbaijan-636713 (E.T. 20.05.2021).

Lindenstrauss, G. (2015). Israel-Azerbaijan: Despite the Constraints, A Special Relationship. Strategic Assessment, 17 (4), s. 69-79.

Markedonov, S.M. ve Suchkov, M.A. (2020). Russia and the United States in the Caucasus: Cooperation and Competition. Caucasus Survey, 8 (2), 2020, s. 179-195.

Mearsheimer, J.J. (2001). The Tragedy of Great Power Politics, New York:W. W. Norton \& Company.

Mehdiyev, M. (2021). Azerbaijan, Israel Expand Defense Cooperation with new Joint venture. Caspian News. https://caspiannews.com/news-detail/azerbaijanisrael-expand-defense-cooperation-with-new-joint-venture-2021-3-26-48/ (E.T. 07.06.2021).

Murinson, A. (2014). The Ties Between Israel and Azerbaijan. Mideast Security and Policy Studies No. 110. Ramat Gan: The Begin-Sadat Center for Strategic Studies.

Olson, R. (2002). The 'Azeri' Question and Turkey-Iran Relations, 2000-2002”, Nationalism and Ethnic Politics, 8(4), s. 61-85.

Özdaşlı, E. (2017). İsrailıin Yeni Çevre Stratejisinde Güney Kafkasya. Bilig, 82, s. 175-200.

Özdaşlı, E., Kodaman, T. (2016). Stratejik Ortaklık Kavramı Bağlamında İsrail Azerbaycan İlişkileri. Ankara: Orion Kitabevi.

Pinfold, R.G. ve Peters, J. (2021). The Limits of Israel's Periphery Doctrine: Lessons from the Caucasus and Central Asia. Mediterranean Politics, 26 (1), s. 25-49.

Pollock, D. (2020). The Baku Balance: How Azerbaijan Juggles Israel and Iran. The Washington Institute: Flkra Forum, https://www.washingtoninstitute.org/policyanalysis/baku-balance-how-azerbaijan-juggles-israel-and-iran (E.T. 28.05.2021).

Rehimov, R. (2021). Zangezur Corridor to Provide New Link Between Turkey, Azerbaijan. Anadolu Agency, https://www.aa.com.tr/en/economy/zangezur-corridor-to-providenew-link-between-turkey-azerbaijan/2260088 (E.T. 05.06.2021).

Rod, M. (2020). Nagorno-Karabakh Conflict Highlights Israel's Strategic Role in Region. The Jewish Insider. https://jewishinsider.com/2020/11/nagorno-karabakh-conflictisrael/ (E.T. 25.05.2021).

Sassonian, H. (2021). Israel Needs to Stop Arming Azerbaijan. The Jerusalem Post. https:// www.jpost.com/opinion/israel-needs-to-stop-arming-azerbaijan-opinion-664115 (E.T. 23.05.2021).

Sneh, E. (2020). Supporting the Azeri Formula in Nagorno-Karabach Conflict. The Jerusalem Post. https:/www.jpost.com/opinion/supporting-the-azeri-formula-innagorno-karabach-conflict-646255 (E.T. 24.05.2021).

Souleimanov, E. ve Ditrych, O. (2007). Iran and Azerbaijan: A Contested Neighbourhood. Middle East Policy, 14(2), s. 101-116.

Temby, O. (2015). What are Levels of Analysis and What do They Contribute to International Relations Theory?. Cambridge Review of International Affairs, 28(4), s. 721-742.

The Jerusalem Post (2020). Azerbaijani Jews Demonstrate in Tel Aviv against Armenian Aggression. https://www.jpost.com/israel-news/azerbaijani-jews-demonstrate-in-telaviv-against-armenian-aggression-638619 (E.T. 27.05.2021). 
The Times of Israel. (2020). Armenian Envoy Expects Israel will Halt Arms Sales to Azerbaijan amid Conflict. https://www.timesofisrael.com/armenian-envoy-expectsisrael-will-halt-arms-sales-to-azerbaijan-amid-conflict/ (E.T. 30.05.2021).

Walt, S.M. (1985). Alliance Formation and the Balance of World Power. International Security, 9(4), s. 3-43.

Walt, S.M. (1987). The Origins of Alliance. New York:Cornell University Press.

Waltz, K.N. (2001). Man, the State and War: A Theoretical Analysis. New York:Columbia University Press.

Wezeman, P.D., Kuimova, A., Smith, J. (2021). Arms Transfers to Conflict Zones: The Case of Nagorno-Karabagh. Stockholm International Peace Research Institute. https:// www.sipri.org/commentary/topical-backgrounder/2021/arms-transfers-conflictzones-case-nagorno-karabakh (E.T. 03.08.2021).

Yurdusev, N. (2007-2008). “Analiz Seviyesi” ve “Analiz Birimi”: Bir Ayrım Argümanı. Uluslararası İlişkiler, 4(16), s. 3-19. 